\title{
Viability Assessment of Light Rail Line Planning: Case Study of Cincinnati Eastern Corridor
}

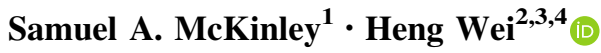

Received: 4 January 2017/Revised: 13 March 2017/Accepted: 28 March 2017/Published online: 8 April 2017

(c) The Author(s) 2017. This article is an open access publication

\begin{abstract}
With increasing environmental concerns, light rail transit (LRT) has drawn attention for consideration in urban transportation planning by various levels of authorities in the US Government. Advocacy groups need an effective method for viability assessment of the alternatives. Environmentalists may want to support LRT, but assessment of its viability is important to provide judgment of any future transportation project. This paper presents a method for LRT viability assessment through a case study of the "Oasis Line," as part of the Eastern Corridor Major Investment Study (MIS) by the Ohio Kentucky and Indiana Council of Governments (OKI). The study attempts to evaluate chances for "success" of the rail transit component of the MIS. An integrated method is used with a traditional four-step-based demand forecast by OKI, and a development of station-based Light Rail Ridership Regression demand forecast by Pelz. The problem to be solved-whether the line has a good enough chance at success to support and advocate for it— did not demand a full rerunning of the models. A review of
\end{abstract}

Heng Wei

heng.wei@uc.edu

Samuel A. McKinley

sam_mckinley@yahoo.com

1 Price Hill Will, Sustainable Places Studio, LLC, Cincinnati Area, KY, USA

2 Beijing University of Technology, Beijing, China

3 Chang' an University, Xian, China

4 Department of Civil and Architectural Engineering and Construction Management, The University of Cincinnati, 792 Rhodes Hall, 2850 Campus Way, Cincinnati, OH 45221-0071, USA

Editors: Haishan Xia and Chun Zhang appropriate literature-largely assessments of already-built light rail lines in other US cities-is used to characterize the predicted ridership as a success or failure. The predicted ridership falls comfortably above the low end of LRT systems in other US cities. The ridership predictions are found favorable to support the Oasis Line. Extensive literature review suggested that the public's assessments behave in an almost entirely political fashion.

Keywords Viability assessment · Light rail transit (LRT) · Diesel Multi-Unit (DMU) · Light Rail Ridership Regression (LRRR) · Ridership · Boarding · LRT station

\section{Introduction and Background}

While rail transportation in the USA is primarily comprised of freight shipments, rail passenger transportation is available but playing a limited role as compared to transportation patterns in many other countries [1]. According to the Bureau of Economic Analysis [2] of US Depart of Commerce, however, consumer using public transportation outgrew spending on new automobiles between 2000 and 2015. In 2015, consumer spending on public transportation exceeded $\$ 100$ billion in the USA for the first time ever [3]. Use of mass transit is usually concentrated in highly urban areas. According to the American Public Transportation Association [4], the three largest public transit agencies by ridership are in New York City, Chicago, and Los Angeles. New York City's Metropolitan Transit Authority serves about one-third of those who use mass transit in the USA [3]. With such increasing concerns with congestion and associated adverse impact on air quality and hence public health, light rail transit (LRT) has drawn attention for 
reexamination and consideration in urban transportation planning at various levels of transportation planning authorities in the USA [3, 5-9].

Government and advocacy groups have called for an effective method for viability assessment of the alternatives. It is the major goal of the rail lines to be supportive of transit, bicycle, and walking-based travel and can reduce reliance on cars as a primary mode of local transportation. It can also help stimulate community enhancement, revitalization, and economic growth opportunities through ongoing service and transit-oriented developments (TODs) that could grow around the line's rail stations. TODs are walkable, mixed-used community spaces that typically include office, retail, residential, and social gathering facilities [10].

As an American environmental organization, Sierra Club has hundreds of thousands of members in chapters located throughout the USA. The Greater Cincinnati Chapter of the Sierra Club (or called the Miami Group) and other environmental groups have worked for years to forestall a major widening and realignment of Ohio Route 32, in eastern Hamilton County. The presented study was part of a Major Investment Study (MIS) by the Ohio Kentucky and Indiana Council of Governments (OKI), the metropolitan planning organization (MPO) for the Greater Cincinnati area which covers four counties located in State of Ohio, three counties in Kentucky and one county in Indian: The Eastern Corridor MIS [11, 12]. It was handled by the Hamilton County Engineer's Office as a Transportation Improvement District (TID) (6-7). In this project, the LRT component of the MIS is termed the "Oasis Line" as it uses existing rail right-of-way with that name.

The Oasis Line rail transit plan had followed the proposed road over a new bridge across the Little Miami. However, the existing railroad tracks that had made much of the rail transit plan relatively cost-effective already have a bridge in place. If the light rail component were truly divorced from the road component, environmentalists would stand a much better chance of stalling the road component and getting rail transit to use the existing bridge. Also, while rail transit still represents increased capacity through the Eastern Corridor, it tends to induce much more compact, less environmentally costly patterns of development [13]. While environmentalists may want to line up strongly in support of the light rail component of the Eastern Corridor Plan, assessment of the viability of the Oasis Line is highly desired to provide convincing or solid analysis to judge success of the future transportation project..

Sierra Club, an environmental organization in the USA that was founded on May 28, 1892, in San Francisco, California, is generally supportive of transportation alternatives to the personal automobile. But they would not want to win this major commitment to rail transit only to have it viewed as a failure, giving a bad name to all fixedguideway modes of mass transit [14]. To minimize this addressed concern, the viability assessment is focused on evaluation of the magnitude or degree of the rail transit line's positive impact on the existing job connectivity with expanding or new non-retail employment, alongside the estimated rider shares potentially attracted by the rail transit plan and its environmental impact. On the other hand, we need to ensure whether the Oasis Line has a reasonable-enough chance of success that Sierra Club can support it without worrying that it will preclude future rail transit projects in the Greater Cincinnati area. From the long run, the Oasis Rail Transit line is desired to be a foundation upon which Greater Cincinnati's envisioned regional rail system could ultimately be built to better connect our region - from Hamilton, Clermont, Butler, and Warren counties in Ohio to Campbell and Kenton counties in northern Kentucky and locations in southern Indiana [10].

The study presented in the paper looks at several results of the Eastern Corridor MIS by OKI [11, 12]. Specifically, the study is an attempt to evaluate the chances for "success" of the rail transit component of the recommendations that resulted from the MIS. The study uses an integrated method with a more traditional "four-step" demand forecast by OKI, and station-based Light Rail Ridership Regression (LRRR) demand forecast for the proposed Oasis Line by Pelz [15]. While it would be preferable to produce original assumptions and modeling, the problem to be solved by this study - whether the Oasis Line has a good enough chance at success for Sierra Club to support and advocate for it—does not demand it. Additionally, a review of appropriate literature-largely assessments of alreadybuilt light rail lines in other US cities-will be used to categorize the predicted ridership as representing a line that is a success or a probable failure.

This paper is organized as follows: the introduction is followed by scope of the study. Then, the methodology section presents the core of the methods used for the study and the results in predicting success of the concerned LRT line and other findings, as well as the analysis of national ranking by ridership as a reference to weigh a possible success or failure of a LRT project. Conclusions are at the end.

\section{Scope of the Study}

The study is motivated to (1) examine the appropriateness and validity of demand forecasting done by traditional "four-step" versus "station-based" LRRR modeling; (2) compare the demand forecasts generated by each and explain why they differ, and what that means for each set's defensibility in public debate; (3) compare both sets to 
what have proved to be successful or unsuccessful lines in other US cities, suggesting various measures; and (4) determine whether demand forecasting predicts the proposed line will likely be popularly judged a "success" or a failure that should not be supported or pursued, based on comparisons with other cities' riderships and how they were judged.

Figure 1 shows the study area. The proposed route of the Oasis Line light rail begins at the transit center at the southern end of downtown Cincinnati, essentially following the Ohio River up until the Little Miami River's confluence with the Ohio. Thence, it follows fairly close to the Little Miami, until crossing the river, either at the Cincinnati neighborhood of Linwood or at the southern middle of the Village of Mariemont. If it crosses at Linwood, it follows State Route 32. If it crosses at Mariemont, it drops down to the southern part of the Village of Newtown. The two alternatives rejoin in the eastern portion of Newtown and then head northeast, to the southern bank of the Little Miami, south of the Village of Terrace Park. The reunited alternatives follow that river until about halfway past the southern border of Milford. From there, the line heads almost due east, to terminate near the junction of US Route 50 and I-275.

Of all the sources in the present study's bibliography that define light rail [15-21], each of them mentions electric power for the rolling stock. The proposed rolling stock for the Oasis Line is actually diesel-powered, called "DMU." DMU stands for Diesel Multi-Unit, and the proposed stock is made by Siemens Company [22]. DMU is used in many applications that would otherwise be described as light rail [23]. In the case of the Oasis Line the frequency of proposed stops, the fact that it serves mostly urban short haul and the morphology of the proposed rolling stock means that it is logical to evaluate it against light rail standards. Siemens' DMUs are available in three gauges, including the standard gauge of the existing Oasis rails. The advantages of DMU are thought in this case to include the fact that it obviates the need for the installation of overhead power and the fact that-with time segregation or perhaps advanced switching and scheduling-it could be certified by the Federal Rail Administration (FRA) to run on freight rails, so the local rail workers' unions might sign on in support.

\section{Methodology}

\subsection{Demand Forecasting Modeling}

In this study, two demand forecasts for the Oasis Line are studied and compared: results using OKI's traditional travel demand model that are released in the Eastern Corridor
Tier One Draft EIS Report (DEIS) [12], and results by Pelz's study [15] in which the station-based LRRR model was used. Both models included station locations. OKI's model basically used public input combined with professional planning expertise, depending upon or referencing no numerical models for station placement. Pelz' study employed a spatial and statistical methodology to determine optimal station locations.

OKI's forecasting models appear to be something of a "black box." The DEIS mentions the input factors first and then gives the outputs of successive model runs. The travel demand modeling adapts the "well-established" four-step modeling process, namely trip generation, trip distribution, mode choice, and trip assignment. The input statistics for the Cincinnati Eastern Corridor were taken from the corridor only, rather than the super-region, as had been done in previous versions [12]. It does not share the actual calculations, which would generally involve some adjustment factors, calibrated to the region [24]. A feedback loop to model the effects of loading roadway segments to the point of congestion was employed.

The black box is the fact that the inputs were fed through a computerized model, OKI/MVRPC RTDM 6.0 (Ohio, Kentucky, and Indiana/Miami Valley Regional Planning Commission Regional Travel Demand Model 6.0), which just means it is a computerized model calibrated to the OKI/MVRPC super-region. This model was used in a "building" process [12], where pieces of the final recommended alternative are added in one at a time. The model is then rerun. These pieces include:

1. Existing + Committed-What facilities are already there, plus those that have been committed for implementation;

2. Regional Baseline-Adds foreseeable facilities to the Existing + Committed model;

3. Transportation System Management-Various management techniques are assumed to be implemented upon the system, and added onto the Regional Baseline model;

4. Expanded Bus-Recommended bus system improvements are added onto the Transportation System Management model;

5. Rail Transit-Built up from the Expanded Bus model, with the Expanded Bus model taken to act as a feeder system for the Oasis Line, plus five different scenarios run with different levels of additional rail lines, including a line along I-71 and the Wasson Line;

6. Highway Multi-Modal Plan-Adds modeling onto the Rail Transit that includes the Rte. 32 expansion and realignment, as well as other roadway improvements;

7. Multi-Modal Plan with Land Use Vision Plan-Adds onto the Highway Multi-Modal Plan model the "Vision Plan" developed for land uses in the corridor. 


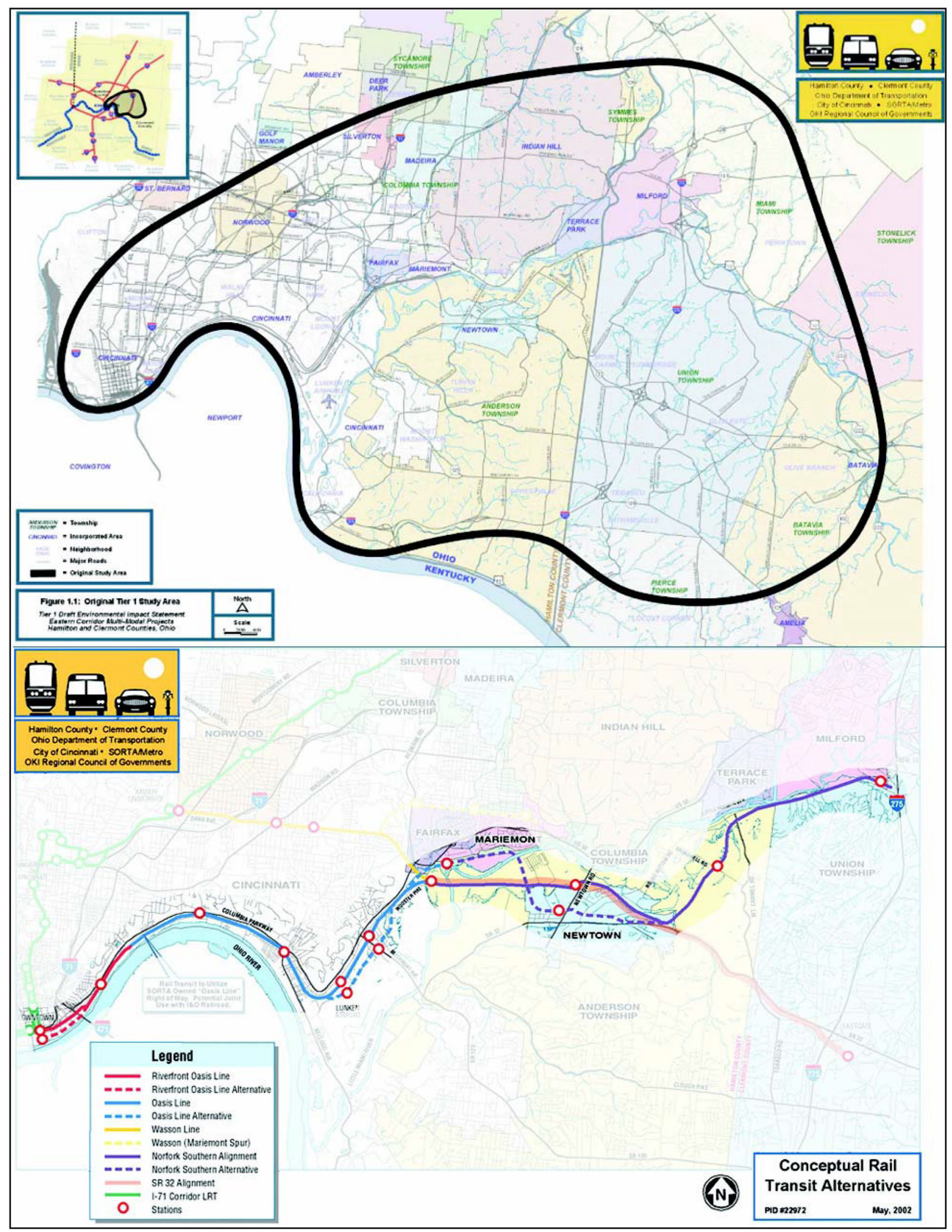

Fig. 1 The Cincinnati Eastern corridor study area and the Oasis Line study area [12] 
All these were modeled for the year 2030, the target year of the authority's next Long-Range Transportation Plan (LRTP). At the end of all the runs, the Oasis Line was projected to have approximately 8000 daily riders, as part of 36,000 daily rail ridership for the whole OKI region including the Wasson and I-71 lines.

Pelz's study [15] was developed from two sources: Kuby et al. [18] and Upchurch [20]. Kuby et al.'s [18] study developed a station-based ridership model, specifically targeted at light rail. They tested 17 variables, through regression analysis, over 268 stations in nine cities with existing light rail systems. Only 12 variables are correlated with the observed boardings. Typical variables are shown in Table 1, along with whether they were hypothesized to be negatively or positively correlated with boardings and whether or not they proved to be significant after regression.

The variables shown in Table 1 are briefly explained as follows:

- Employment within walking distance-The job locations within $1 / 2$ mile of the station;

- Population within walking distance-Population living within $1 / 2$ mile;

- Airport-A dummy variable, one if the station served airport terminals, zero if not;

- International border-Also a dummy variable, reflecting whether the station serves and international border;

- College enrollments-Whether a station had a college within walking distance;

- CBD dummy variable-Whether a station was located within a Central Business District;
- Park-and-ride spaces-The number of parking spaces available at stations;

- Bus connections-The number of intersecting bus lines;

- Other rail lines-A 0-1 dummy variable, reflecting only whether the station was colocated with one for another type of rail transit;

- Heating and cooling degree-days-The number of days above or below $65^{\circ} \mathrm{F}$, times the absolute value of the degrees from 65;

- PMSA population-The population of the Primary Metropolitan Statistical Area;

- Terminal station-A dummy variable, reflecting whether a given station was the last one on the line;

- Station spacing-The distance between a the edge of a $1 / 2$ mile buffer around a given station and the $1 / 2$ mile buffer around the next station;

- Designated transfer station-Whether a station offers transfer to another light rail line;

- Normalized accessibility (centrality)_-The average travel time for each station, divided by the highest average travel time for its system;

- Percentage of PMSA employment covered by systemWhat percentage of the PMSA's employment lies within $1 / 2$ mile walking distance of any station in the system; and.

- Percent renters within walking distance-The percentage of the population within $1 / 2$ mile of stations who rent their homes.

In this modeling, statistics were used for areas within a $1 / 2$ mile "buffer" around each station. In some cases,

Table 1 Variables [18]

\begin{tabular}{llc}
\hline Independent variable & Hypoth. correlation & Significant \\
\hline Employment within walking distance & + & Yes \\
Population within walking distance & + & Yes \\
Airport & + & Yes \\
International border & + & Yes \\
College enrollments & + & No \\
CBD dummy variable & + & No \\
Park-and-ride spaces & + & Yes \\
Bus connections & + & Yes \\
Other rail lines & + & No \\
Heating and cooling degree-days & - & Yes \\
PMSA population & + & No \\
Terminal station & + & Yes \\
Station spacing & + & No \\
Designated transfer station & + & Yes \\
Normalized accessibility & - & Yes \\
Percentage of PMSA employment covered by system & + & Yes \\
Percent renters within walking distance & + & Yes \\
\hline
\end{tabular}


statistics were only available by census block and a simple calculation of the percentage of the census block covered by the buffer was conducted. After performing the regressions and calibrations, Kuby et al. [18] developed the equation:

$$
\begin{aligned}
\text { Boardings }= & 1584+(0.023 \text { Employment })+(0.092 \text { Population }) \\
& +(915 \text { Airport })+(12,055 \text { Border }) \\
& +(0.0774 \text { Park-and-ride })+(123 \text { Bus }) \\
& -(1.52 \text { Degree-days })+(660 \text { Terminal }) \\
& +(5735 \text { Transfer })-(1872 \text { Centrality }) \\
& +(1301 \text { Employment Coverage }) \\
& +(624 \text { Percent Renters })+\text { Error. }
\end{aligned}
$$

The border variable was left off as zero in every case, as the nearest international border to Cincinnati is about $5 \mathrm{~h}$ drive by automobile. The error variable only makes sense when trying to calibrate existing systems to each other.

Based on the method resulting from Upchurch's study [20], a geographical information system (GIS)-based model was developed, which resulted in a surface whose high points suggest the ideal station locations. Six criteria were used with this model: employment density, population density, feeder bus service, location on the alignment, location at a street intersection, and a minimum of $1 / 2$ mile distance from the next station.

A composite of employment and population densities, plus feeder service within $1 / 2$ mile of the rail alignment, was made. Statistics for population density were only available for full census blocks, so simple percentages of the blocks were used according to how much of their area fell within the buffer. Likewise, employment density was available by transportation analysis zone (TAZ), so the same clipping procedure was carried out on those. While this is not perfectly fine-grained, it is much more precise to the alignment than is OKI's full-corridor methodology.

Next, these areas' scores were turned into "heights" within the GIS model. This could then be overlayed on the street map, with the highest points at street intersections, but not within $1 / 2$ mile of another station, being chosen as stations. Finally, Pelz' models produced boardings (which can be equated with unlinked trips) of 9133 for the Oasis Line in project year 2030 [15]. What is noteworthy is that his models produced about $17 \%$ higher ridership predictions for the western 8 miles of the Oasis Line than OKI's models for its entire 17-mile length. Population and especially employment densities start to drop off just east of Pelz' study area, so perhaps that helps to explain why his station-based model in that area predicts higher numbers than OKI's whole-corridor model.

\subsection{Success Assessment Through Ridership Forecasting}

At the heart of the present study is a basic decision: would the Oasis Line likely be perceived as successful enough that it would not damage the chances for further rail transit in the Greater Cincinnati area? Sierra Club has found that the fully recognized and allocated outcomes of rail transit are, in general, vastly better for the environment than are the outcomes of road projects [13]. So, if the public in the Greater Cincinnati area would likely perceive the Oasis Line as a success, and therefore demand and support more rail transit for the area, then Sierra Club should probably support the Oasis Line. Conversely, if it is predictable that the public would see the Oasis Line as a failure, a "boondoggle," or a giant "pork" project, then Sierra Club should probably not be associated with that. Moreover, Sierra Club should probably work actively against it in that case, as it would obviously reduce the chances to build any further rail transit.

The original model of success for the present study was a simple one: hold the ridership predictions of the two models up against the observed ridership of already-built systems whose constituents seemed to perceive them as successful. Some discussion of how likely other cities' results were to predict perceptions in Greater Cincinnati would be necessary, but it was hoped that a review of articles in those cities would reveal public perceptions.

As it turned out, this model provides only scant, almost anecdotal evidence. The American Public Transit Association (APTA) lists current ridership statistics for only 26 existing US light rail systems for the first quarter of 2008 [16]. One of those, in Charlotte, NC, was not developed enough to have a full-quarter's statistics. Of the rest, most are too old to have a body of readily available newspaper articles representing public reaction to them. The organization "Light Rail Now Project" [19] features articles on just about every system, but they are all attributed to the organization, and its name might suggest bias.

A series of five articles were uncovered in the Houston Chronicle [17], wherein the author traveled to five cities to evaluate their systems. The cities were San Diego, Denver, Cleveland, Portland, OR, and Dallas, TX. However, he wrote these articles in the run-up to a vote on light rail for Houston, TX. Furthermore, they appeared on the Web site of the organization Bicycle Austin [17], which was promoting efforts in Austin, TX, to build a light rail system. Again, one could predict which way their argument would land.

Many, many hours of research gave an impression that light rail is so politically charged that local sources-and even most national sources-are unlikely to give much 
sense of the "public" reaction to the projects. Rather, they show their authors' biases, with supporting statistics interpreted in predictable directions.

In the end, the best evaluation is probably to use the most basic-least prone to bias-statistics and apply good sense and logic to them. Therefore, the following section will show where OKI's and Pelz' predictions rank the Oasis Line versus the first quarter 2008 ridership APTA reports [16]. The "good sense and logic" part will come in with various attempts to equalize and discuss them.

\section{Evaluation of the Proposed Oasis Line}

At the risk of repetitiveness, the real standard of evaluation of the present study is whether the Oasis Line has a reasonable-enough chance of success that Sierra Club can support it without worrying that it will preclude future rail transit projects in the Greater Cincinnati area. Given that, we will evaluate first its chances of being built at all. Next we will look at its rank-using both OKI's and Pelz' ridership predictions-against other whole light rail systems in the USA

The project is listed for funding in the "Fiscally-Constrained Detailed Project Scoring" section of OKI's 2030 Long-Range Transportation Plan [25]. Tables summarizing OKI's scoring criteria are available in that report. The project scores 49 out of a possible 105 points in this list. The cutoff point is 47 . That is, anything scoring 47 points or less will not be submitted for funding, while the projects that score 47.4 and higher will. The scoring criteria are certainly vulnerable to charges of subjectivity and pro-road bias, but the Oasis Line made it, in any case. On the other hand, the I-71 rail transit alignment and study for the Wasson Line did not make the cut, which could have an effect on the ridership models of both Pelz and OKI.

In a strict ranking by ridership versus APTA's 1st Quarter 2008 Light Rail Agency Statistics as shown in Table 2, both Pelz' and OKI's predictions rank fairly well. They are well down the list, but by no means low outliers. As discussed earlier, though, the systems listed vary widely by many possibly relevant criteria, such as age of system, city characteristics, system track-mile length, and system network topology.

It is probably best to use Pelz' and OKI's 2030 projections and just keep in mind that they are predictions for a fully mature line. The fact that they fall midway between Cleveland's and New Orleans' ridership is then perhaps appropriate. Table 2 immediately begs the question of how comparable the Oasis Line might really be to these other systems. For instance, while the Kuby regression found that PMSA population did not matter that was for station boardings. The APTA statistics are for entire systems, and common sense tells us that PMSA population probably does matter over the entire system. Speaking of stations, might that variable make a difference? As shown in Table 3, the Oasis Line is presented on a boardings-permile basis and the Pelz and OKI forecasts really diverge. Even the OKI numbers stay out of the bottom two quintiles, while Pelz' forecast puts the Oasis Line halfway down the second quintile. As stated before, both population and employment start to get more sparse in the area around the Oasis Line, just about at the eastern limit of Pelz analysis, so it is quite possible that forecasts for an alignment the length of the one Pelz used would not drop off much.

Finally, since the Kuby model focused on stations, perhaps boardings per station might offer some insights, as shown in Table 4. Interestingly, this gives very similar rankings for the Oasis Line. The Pelz forecast is still in the second quintile, although a bit farther down, while OKI falls in the same 11th from the bottom position, or just into the third quintile. One important factor to note in the other systems is that the San Francisco Muni number is skewed very badly. A footnote to APTA's table says that streetside stops may not be counted as stations. Obviously, Muni relies heavily on these, considering they show only nine stops for 72.9 track miles.

Two sets of demand forecasts and evaluations against national light rail ridership statistics predict that ridership on the Oasis Line would be strong enough to support the Oasis Line. The above results also imply a sign of success for the proposed Oasis Line based on the ridership forecasting. The ridership numbers say the Oasis Line would be a credible light rail project and that Sierra Club can support it as long as it is not bound with the Rte. 32 expansion. Results shown in Tables 2 through 4 give a sense that the Oasis Line would be well into the thick of the national rankings, which is what is meant by "qualitative." Perhaps a truly quantitative route to evaluation would be through Kuby's model. Rather than just using it to predict ridership, perhaps given a forecast, its parameters could be used to normalize all the cities with light rail and give a "true" ranking that way.

\section{Discussions and Conclusions}

To date, there exist no real quantitative measures of success for a light rail system. Paul M. Weyrich and William S. Lind in "Does Transit Work? A Conservative Reappraisal" [21] pointed out one very good reason (among many) for this-light rail never turns a profit. They go on to point out that no other transportation systems do either (nobody complains that sidewalks don't turn a profit), but could take it a step farther. Whether or not it is fair for light rail to be held to a profitability standard, the fact is that 
Table 2 Pelz and OKI

Forecasts Ranked versus

Existing Systems [12], [15, 16]

\begin{tabular}{|c|c|c|c|}
\hline \multicolumn{4}{|c|}{ Non-linked avg. daily ridership 1st quarter 2008} \\
\hline Agency & State & City & AVG daily boardings \\
\hline Massachusetts Bay TR Auth & MA & Boston & 226,186 \\
\hline San Francisco Muni Rwy & $\mathrm{CA}$ & San Francisco & 118,534 \\
\hline Los Angeles County MTA & $\mathrm{CA}$ & Los Angeles & 114,473 \\
\hline Tri-County Metro Trp Dist & OR & Portland & 92,053 \\
\hline Southeastern Penn TA & PA & Philadelphia & 90,552 \\
\hline San Diego Trolley, Inc. & $\mathrm{CA}$ & San Diego & 88,368 \\
\hline Bi-State Dev Agency & MO & Saint Louis & 61,532 \\
\hline New Jersey Transit Corp & NJ & Newark & 55,163 \\
\hline Regional Trp District & $\mathrm{CO}$ & Denver & 53,307 \\
\hline Dallas Area Rapid Transit & TX & Dallas & 50,275 \\
\hline Sacramento Reg Tr Dist & $\mathrm{CA}$ & Sacramento & 40,815 \\
\hline Metro Tr Auth of Harris Co & $\mathrm{TX}$ & Houston & 34,568 \\
\hline Santa Clara Valley Trp Auth & $\mathrm{CA}$ & San Jose & 26,534 \\
\hline Metro Transit & $\mathrm{MN}$ & Minneapolis & 22,674 \\
\hline Maryland Transit Admin & MD & Baltimore & 20,301 \\
\hline Port Auth of Allegheny Co & PA & Pittsburgh & 18,769 \\
\hline Niagara Frontier Trp Auth & NY & Buffalo & 18,249 \\
\hline Regional Transit Auth & LA & New Orleans & 10,997 \\
\hline Oasis Line & $\mathbf{O H}$ & Cincinnati & 9133 (Pelz 2030 Proj) \\
\hline Oasis Line & $\mathbf{O H}$ & Cincinnati & 8000 (OKI 2030 Proj) \\
\hline Greater Cleveland Reg TA & $\mathrm{OH}$ & Cleveland & 6963 \\
\hline Sound Transit & WA & Seattle & 2436 \\
\hline Memphis Area Transit Auth & $\mathrm{TN}$ & Memphis & 2173 \\
\hline Hillsborough Area Reg TA & FL & Tampa & 1352 \\
\hline King County Dept of Trp & WA & Seattle & 874 \\
\hline Kenosha Transit & WI & Kenosha & 73 \\
\hline City of Galveston/Island $\mathrm{Tr}$ & $\mathrm{TX}$ & Galveston & 69 \\
\hline
\end{tabular}

Bold indicates if the concerned items are statistically signifincant at $95 \%$ level or not
Americans simply are not familiar enough with it to appraise it by other standards. That is, in America "the market" is the fallback standard and often the primary standard. Where nobody can agree on another, it is supposed that the market will sort it out. At the very least, it is supposed that light rail's benefit/cost ratio should be competitive with roads.

However, as Weyrich and Lind go on to point out, this is not very productive, either. Rail transit and roads serve different purposes and operate in different cost allocation and geographical universes. The main thesis of their study is that rail should only be held responsible for "rail-competitive" trips, where it turns out to do quite well. When the focus is only on those who are served by convenient, highquality rail, and for trips which make sense on rail, they find that Chicago's system, for instance, captures as many as $50 \%$ of the trips. Since the system operates primarily in areas where automobile congestion is worst, and eminent domain and parking costs are the highest, it is highly costeffective in its own universe.

Another author, on the Light Rail Now Web site [19] (17), points out that, while light rail is often maligned for not having much impact on a region's transportation problems, it can be proved to have a dramatic impact within its own corridor, especially on signalized arterial roads within the corridor. The author further points out that no single transportation project has much impact on an entire region's transportation, and in fact increased roadways often exacerbate the problems they are meant to solve through induced demand.

The present study attempts to hold up forecast numbers for comparison to systems in other cities. It even went further and tried to equalize the data by comparing trips per track mile and trips per station. While these procedures looked quantitative, they probably work best in a qualitative sense. With a universe of only 25 systems, how valid 
Table 3 Pelz and OKI 2030 forecasts ranked against national light rail systems, boardings per track mile [12], [15, 16]

\begin{tabular}{|c|c|c|c|c|c|}
\hline Agency & State & City & AVG daily boardings & Track miles & Boardings/track mile \\
\hline Massachusetts Bay Tr Auth & MA & Boston & 226,186 & 78.0 & 2899.8 \\
\hline Metro $\operatorname{Tr}$ Auth of Harris Co & $\mathrm{TX}$ & Houston & 34,568 & 20.0 & 1728.4 \\
\hline Regional Trp District & $\mathrm{CO}$ & Denver & 53,307 & 32.1 & 1660.6 \\
\hline San Francisco muni Rwy & $\mathrm{CA}$ & San Francisco & 118,534 & 72.9 & 1626.0 \\
\hline Sound Transit & WA & Seattle & 2436 & 1.8 & 1353.5 \\
\hline Niagara Frontier Trp Auth & NY & Buffalo & 18,249 & 14.1 & 1294.3 \\
\hline Oasis Line & $\mathbf{O H}$ & Cincinnati & 9133 & 8.0 & 1141.6 (Pelz 2030 Proj) \\
\hline Los Angeles County MTA & $\mathrm{CA}$ & Los Angeles & 114,473 & 116.3 & 984.3 \\
\hline Tri-County Metro Trp Dist & OR & Portland & 92,053 & 97.9 & 940.3 \\
\hline Metro Transit & $\mathrm{MN}$ & Minneapolis & 22,674 & 24.2 & 936.9 \\
\hline San Diego Trolley, Inc. & $\mathrm{CA}$ & San Diego & 88,368 & 97.0 & 911.0 \\
\hline New Jersey Transit Corp & $\mathrm{NJ}$ & Newark & 55,163 & 67.1 & 822.1 \\
\hline Bi-State Dev Agency & $\mathrm{MO}$ & Saint Louis & 61,532 & 81.0 & 759.7 \\
\hline Sacramento Reg Tr Dist & $\mathrm{CA}$ & Sacramento & 40,815 & 62.6 & 652.0 \\
\hline Southeastern Penn TA & PA & Philadelphia & 90,552 & 171.0 & 529.5 \\
\hline Dallas Area Rapid Transit & $\mathrm{TX}$ & Dallas & 50,275 & 101.2 & 496.8 \\
\hline Oasis Line & $\mathbf{O H}$ & Cincinnati & 8000 & 17.0 & 470.6 (OKI 2030 Proj) \\
\hline Regional Transit Auth & LA & New Orleans & 10,997 & 26.0 & 423.0 \\
\hline Hillsborough Area Reg TA & FL & Tampa & 1352 & 3.2 & 422.4 \\
\hline Port Auth of Allegheny Co & PA & Pittsburgh & 18,769 & 44.8 & 419.0 \\
\hline King County Dept of Trp & WA & Seattle & 874 & 2.1 & 416.0 \\
\hline Maryland Transit admin & MD & Baltimore & 20,301 & 54.0 & 375.9 \\
\hline Santa Clara valley Trp Auth & $\mathrm{CA}$ & San Jose & 26,534 & 71.5 & 371.1 \\
\hline Greater Cleveland Reg TA & $\mathrm{OH}$ & Cleveland & 6963 & 33.0 & 211.0 \\
\hline Memphis Area Transit Auth & $\mathrm{TN}$ & Memphis & 2173 & 10.5 & 206.9 \\
\hline Kenosha Transit & WI & Kenosha & 73 & 1.9 & 38.2 \\
\hline City of Galveston/Island $\mathrm{Tr}$ & $\mathrm{TX}$ & Galveston & 69 & 5.0 & 13.8 \\
\hline
\end{tabular}

Bold indicates if the concerned items are statistically signifincant at $95 \%$ level or not

are city-to-city comparisons? For instance, San Francisco has had continuous rail transit service for several generations, and its light rail operates in coordination with multiple layers that include the BART heavy rail subway, CalTrains commuter rail, cable cars, and a huge bus system. Its continuous emphasis on public transit and its highly constrained geography give it density that would be expected to yield high ridership. Another example, Cleveland's RTA, does not show well on the national rankings. However, it probably has a good chance of survival, since it serves some of the wealthiest suburbs in the nation-suburbs which have grown up and formed, dependent on light rail.

At this point, if a debate opens up, the ridership may be only one among many factors argued. Somebody may assert that the line could give enough accessibility to foreclose any desire for the Rte. 32 expansion. Another member may question whether it would present similar problems in crossing the Little Miami River. Finally, one hopes that a politically sensitive member would speak to the attitude of the community and how the project is likely to be received and what other battles it may spawn. And that's just for a subcommittee of one organization, at a local level! So the final judgments are not only qualitative, but highly politicized, as with any question involving large expenditures of public monies.

The answer to the central question of the present study is that the Oasis Line will probably have enough riders that Sierra Club won't get hurt on that front, but there is a lot more to it than that. While the ridership data cannot be available because the Oasis Line Corridor has not been fully completed and put into operation yet, the trend will be monitored and then analyzed in the future report. Also, the study and associated assessment method is also expected to provide an experience as a reference for future similar projects in other areas in the USA [26]. 
Table 4 1st Quarter 2008 Light rail agency ridership, boardings per station [12], [15, 16]

Q1 2008 non-linked avg. daily ridership ranked by boardings/station

\begin{tabular}{|c|c|c|c|c|c|}
\hline Agency & State & City & AVG daily boardings & Number of stations & Boardings/station \\
\hline San Francisco Muni Rwy & CA & San Francisco & 118,534 & 9 & $13,170.5$ \\
\hline Massachusetts Bay Tr Auth & MA & Boston & 226,186 & 70 & 2231.2 \\
\hline Los Angeles County MTA & $\mathrm{CA}$ & Los Angeles & 114,473 & 49 & 2336.2 \\
\hline Regional Trp District & $\mathrm{CO}$ & Denver & 53,307 & 23 & 2317.7 \\
\hline Bi-State Dev Agency & $\mathrm{MO}$ & Saint Louis & 61,532 & 28 & 2197.6 \\
\hline Metro Transit & $\mathrm{MN}$ & Minneapolis & 22,674 & 16 & 2160.5 \\
\hline Southeastern Penn TA & PA & Philadelphia & 90,552 & 46 & 1968.5 \\
\hline San Diego Trolley, Inc. & $\mathrm{CA}$ & San Diego & 88,368 & 49 & 1803.4 \\
\hline SORTA & $\mathbf{O H}$ & Cincinnati & 9133 & 6 & 1522.2 (Pelz 2030 Proj) \\
\hline Tri-County Metro Trp Dist & OR & Portland & 92,053 & 62 & 1484.7 \\
\hline Dallas Area Rapid Transit & $\mathrm{TX}$ & Dallas & 50,275 & 34 & 1478.7 \\
\hline Metro Transit & $\mathrm{MN}$ & Minneapolis & 22,674 & 17 & 1333.7 \\
\hline Regional Transit Auth & LA & New Orleans & 10,997 & 9 & 1221.9 \\
\hline Niagara Frontier Trp Auth & NY & Buffalo & 18,249 & 15 & 1216.6 \\
\hline New Jersey Transit Corp & $\mathrm{NJ}$ & Newark & 55,163 & 49 & 1125.8 \\
\hline Sacramento Reg Tr Dist & $\mathrm{CA}$ & Sacramento & 40,815 & 41 & 995.5 \\
\hline SORTA & $\mathbf{O H}$ & Cincinnati & 8000 & 9 & 888.90 (OKI 2030 Proj) \\
\hline Port Auth of Allegheny Co & PA & Pittsburgh & 18,769 & 25 & 750.8 \\
\hline Maryland Transit Admin & MD & Baltimore & 20,301 & 32 & 634.4 \\
\hline Santa Clara Valley Trp Auth & $\mathrm{CA}$ & San Jose & 26,534 & 57 & 465.5 \\
\hline Sound Transit & WA & Seattle & 2436 & 6 & 406.0 \\
\hline Memphis Area Transit Auth & $\mathrm{TN}$ & Memphis & 2173 & 7 & 310.4 \\
\hline Greater Cleveland Reg TA & $\mathrm{OH}$ & Cleveland & 6963 & 34 & 204.8 \\
\hline Hillsborough Area Reg TA & FL & Tampa & 1352 & 8 & 169.0 \\
\hline King County Dept of Trp & WA & Seattle & 874 & 9 & 97.1 \\
\hline Kenosha Transit & WI & Kenosha & 73 & 2 & 36.3 \\
\hline City of Galveston/Island $\mathrm{Tr}$ & $\mathrm{TX}$ & Galveston & 69 & 3 & 23.1 \\
\hline
\end{tabular}

Bold indicates if the concerned items are statistically signifincant at $95 \%$ level or not

Acknowledgements This research was supported by the University of Cincinnati, Cincinnati, Ohio. The authors also express gratitude to the Miami Group of the Sierra Club for exposing many of the issues that gave rise to this study. The results and ideas presented in the paper represent the authors' points of view only.

Open Access This article is distributed under the terms of the Creative Commons Attribution 4.0 International License (http://creative commons.org/licenses/by/4.0/), which permits unrestricted use, distribution, and reproduction in any medium, provided you give appropriate credit to the original author(s) and the source, provide a link to the Creative Commons license, and indicate if changes were made.

\section{References}

1. Wikipedia (2017) "Rail transportation in the United States." Available at https://en.wikipedia.org/wiki/Rail_transportation_ in_the_United_States. Accessed 9 March 2017

2. Bureau of Economic Analysis (BEA) (2017) National data. Accessible at https://www.bea.gov/regional/index.htm. Accessed 9 March 2017
3. Hickman L (2016) "The rising demand for public transport in the US". Accessible at http://blog.marketresearch.com/the-risingdemand-for-public-transport-in-the-us. Accessed 9 March 2017

4. American Public Transportation Association (APTA) (2017) Public transportation fact book. Accessible at http://www.apta. com/resources/statistics/Pages/transitstats.aspx. Accessed 7 March 2017

5. Brown JR, Neog D (2008) "Urban structure and transit ridership: a reexamination of the relationship in the United States." In: Compendium of papers CD-ROM, 87th transportation research board annual meeting, January 13-17, 2008, in Washington, DC

6. Federal Highway Administration (FHWA) (2005) Traffic congestion and reliability: trends and advanced strategies for congestion mitigation. Available at http://www.ops.fhwa.dot.gov/ congestion_report/index.htm

7. Pages ER, Lombardozzi B, Woolsey L (2016) The emerging U.S. rail industry: opportunities to support American manufacturing and spur regional development. Available at https://www.nist. gov/sites/default/files/documents/mep/Rail-Report.pdf. Accessed 9 March 2017

8. Schrank D, Lomax T (2007) The 2007 urban mobility report. Available at http://mobility.tamu.edu/ 
9. Weisbrod G, Fitzroy S (2008) "Defining the range of urban congestion impacts on freight and their consequences for business activity." In: compendium of papers cd-rom, 87th transportation research board annual meeting, 13-17 Jan 2008, in Washington, DC

10. Eastern Corridor Program (ECP) (2017) "Oasis rail transit overview." Available at http://easterncorridor.org/projects/oasisrail-transit/oasis-rail-transit-project-overview/. Accessed 9 March 2017

11. Ohio, Kentucky, and Indiana Council of Governments (OKI) (1999) 1999-eastern corridor major investment study (MIS). Available at http://www.easterncorridor.org. Accessed 30 May 2008

12. Ohio, Kentucky, and Indiana Council of Governments (OKI) (2005) Eastern corridor tier one draft EIS. Available at http:// www.easterncorridor.org. Accessed 29 May 2008

13. Sierra Club (2008) "Stop sprawl." Available at www.sierraclub. org/sprawl. Accessed 8 June 2008

14. McKinley SA (2008) A feasibility analysis of hamilton county's proposed oasis light rail line through traditional and advanced demand forecasting vs. best practices. In: Course project report for CEE605 travel demand forecasting offered at University of Cincinnati, Spring Quarter, 2008

15. Pelz ZL (2007) A station level analysis of competing light rail alternatives in cincinnati's eastern corridor. Master's thesis in community planning approved by the University of Cincinnati, June 2007, University of Cincinnati: Cincinnati

16. American Public Transit Association (APTA) (2008) Light rail agency ridership for Q1 2008. Available at www.apta.com/ research/stats/rail//rmiles.cfm. Accessed 1 June 2008
17. Hoffman K (2000) "It's a smooth ride in mile high city," Houston Chronicle June 6, 2000. Available at http://bicycleaus tin.info/rail/Houston-chronicle-06-06-00.html. Accessed 9 June 2008

18. Kuby M, Barranda A, Upchurch CD (2004) Factors influencing light-rail station boardings in the United States. Transp Res Part A 38:223-247

19. Light Rail Now (LRN) (2017) "Light rail now! light rail progress." Available at www.lightrailnow.org. Accessed 3 June 2008; re-accessed 20 Jan 2017

20. Upchurch CD (2005) A spatial decision support system for predicting light-rail transit ridership in phoenix. Master's thesis approved by Arizona State University, September 2005

21. Weyrich PM, William OSL (1999) "Does transit work? A conservative reappraisal." Available at http://www.apta.com/ research/info/online/weyrich2new2.cfm. Accessed 9 June 2008

22. Portune T (2008) April 10, 2008 interview by Author, with other members of Sierra Club

23. Siemens AG (2008) Light rail system references (Internet database). Available at http://references.transportation.siemens.com/ refdb

24. Ortuzar JdD, Willumsen LG (2001) Modelling Transport Third Edition 2001. Wiley, Chichester

25. Ohio, Kentucky, and Indiana Council of Governments (OKI) (2008) DRAFT 2030 OKI regional transportation plan update. Available at http://www.oki.org. Accessed 9 May 2008

26. HDR (2016) OASIS rail conceptual alternative solutions HAM/ CLE-OASIS rail corridor. In: PID No. 86463 final report for Ohio Department of Transportation. 8 Feb 2016 